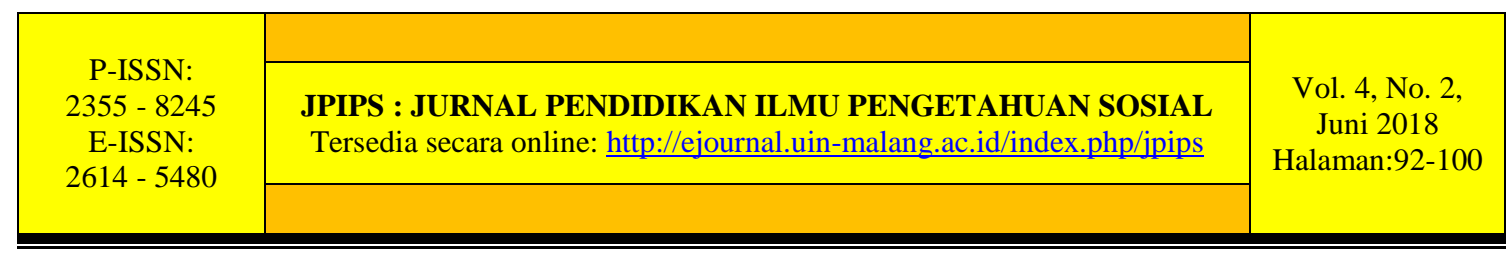

\title{
MEDIA PEMBELAJARAN BERBASIS AUDIO VISUAL DALAM MENINGKATKAN HASIL BELAJAR IPS TERPADU DI MTS NEGERI 1 PASURUAN
}

\author{
Muhammad Sofi Rifandi \\ Universitas Islam Negeri Maulana Malik Ibrahim Malang \\ sofi@gmail.com
}

\begin{abstract}
Abstrak: Audio visual merupakan salah satu media pembelajaran yang dipergunakan dalam meningkatkan hasil belajar siswa karena media audio visual membuat siswa belajar lebih semangat dalam mengikuti pembelajaran. Tujuan penelitian ini adalah untuk: (1) Untuk mendeskripsikan pelaksanaan pemanfaatkan media pembelajaran IPS Terpadu dalam siswa kelas VII di MTs Negeri 1 Pasuruan. (2) Untuk mengetahui hasil belajar pemanfaatkan media pembelajaran untuk mata pelajaran IPS Terpadu Dalam Siswa Kelas VII Di MTs Negeri 1 Pasuruan. (3) Untuk mendeskripsikan menjelaskan bagaimana problematika pemanfaatan media pembelajaran IPS Terpadu dalam siswa kelas VII Di MTs Negeri 1 Pasuruan. Pendekatan yang digunakan adalah pendekatan kualitatif deskriptif yang dilaksanakan selama tiga bulan. Hasil penelitian menunjukkan bahwa (1) pelaksanaan pemanfaatan media pembelajaran guru menggunakan media audio visual dengan memakai LCD yang ada di madrasah, guru bisa menggunakan media belajar dengan menerengkan apa yang ada di foto atau di video tersebut tentang materi pembelajaran yang telah diterangkan. (2) hasil belajar siswa setelah guru memanfaatkan media audio visual pada mata pelajaran IPS terpadu sangat baik sekali. Rata-rata siswa banyak mendapatkan hasil yang baik yaitu dengan nilai 8,5. (3) faktor pendukungnya yaitu dengan adanya fasilitas sarana prasarana yang memadai, motivasi dan etos kerja para pendidik dalam menggunakan media pembelajaran berbasis audio visual, kedisiplinan siswa dalam mengikuti kegiatan belajar mengajar di kelas. Sedangkan faktor penghambatnya yaitu kurangnya kesadaran pendidik dalam pemanfaatan media pembelajaran berbasis audio visual di madrasah.
\end{abstract}

\section{Kata kunci: Audio Visual, Hasil Belajar}

Abstract: The purposes of the research are: (1) To describe the implementation of the utilization of learning media of Integrated Social Studies Subjects of the Students of Class VII at Public Junior High School 1 of Pasuruan. (2) To know the learning result of the utilization of learning media Integrated Social Studies Subjects of the Students of Class VII at Public Junior High School 1 of Pasuruan. (3) To describe and explain the problems of the utilization of Integrated Social Studies Subjects of the Students of Class VII at Public Junior High School 1 of Pasuruan To achieve the objectives above, it had used descriptive qualitative approach for three months. The key instruments are the researcher, and the collection techniques used observation and interviews. Data can be used by reducing relevant data, exposing data and drawing conclusions. The results of the research showed that (1) the implementation of learning media utilization, the teacher uses audiovisual media using LCD at school, the teacher can use the learning media by using the photo or the video about the learning material that has been explained. (2) the student learning outcomes after utilizing the audiovisual media on integrated Social Science subjects are very well. The average student gets a lot of good 
results with a value of 8.5. (3) the supporting factors are the facilities of adequate infrastructure, motivation and work ethics of educators in using learning media based on audiovisual, the student's discipline in following the teaching and learning activities in the class. The inhibiting factors are the lack of awareness of educators in the utilization of learning media based on audiovisual at school.

\section{Keywords: Audio Visual, Learning Outcomes}

\section{PENDAHULUAN}

Belajar adalah suatu proses yang kompleks yang terjadi pada diri setiap orang sepanjang hidupnya. Proses belajar itu terjadi karena adanya interaksi antara seseorang dengan lingkungannya. Oleh karena itu belajar dapat terjadi kapan saja dan dimana saja. Salah satu pertanda bahwa seseorang itu belajar adalah adanya perubahan tingkah laku pada diri orang itu yang mungkin disebabkan oleh terjadinya, perubahan pada tingkat pengetahuan, keterampilan, atau sikapnya. Interaksi yang terjadi selama proses belajar tersebut dipengaruhi oleh lingkungannya, yang antara lain terdiri atas murid, guru, petugas perpustakaan, kepala sekolah, bahan atau materi pelajaran (buku, modul, selebaran, majalah, rekaman video atau audio, dan yang sejenisnya), dan berbagai sumber belajar dan fasilitas (proyektor overhead, perekam pita audio dan video, radio, televisi, komputer, perpustakaan, laboratorium, pusat sumber belajar, dan lain-lain) (Arsyad, 2002).

Pada hakekatnya kegiatan belajar mengajar adalah satu proses komunikasi, proses komunikasi ini harus diwujudkan melalui kegiatan penyampaian dan tukar menukar pesan atau informasi oleh setiap guru dan peserta didik. Pesan atau informasi pendidikan dapat berupa pengetahuan, keahlian, pengalaman dan sebagainya. Melalui komunikasi pesan dimungkinkan bisa diserap oleh semua orang. Demikian halnya dalam proses komunikasi perlu digunakan sarana dalam proses mengajar yang membantu proses komunikasi yang disebut media (Sudjana, 2002).

Perkembangan ilmu penegtahuan dan teknologi semakin mendorong upayaupaya pembaharuan dalam pemanfaatan hasil-hasil teknologi dalam proses belajar. Para guru dituntut agar mampu menggunakan alat-alat yang dapat disediakan oleh sekolah, dan tidak tertutup kemungkinan bahwa alat-alat tersesuai dengan perkembangan dan tuntutan zaman. Guru sekurang-kurangnya dapat menggunakan alat yang murah dan efesien yang meskipun sederhana dan bersahaja tetapi merupakan keharusan dalam upaya mencapai tujuan pengajaran yang diharapkan. Disamping mampu menggunakan alat-alat yang tersedia, guru juga dituntut untuk dapat mengembangkan keterampilan membuat media pengajaran yang akan digunakannya apabila media pengajaran yang akan digunakannya apabila media tersebut belum tersedia. Untuk itu guru harus memiliki pengetahuan dan pemahaman yang cukup tentang pengajaran, yang meliputi (Arsyad, 2002):

1. Media sebagai alat komunikasi guna lebih mengefektifkan proses belajar mengajar.

2. Fungsi media dalam rangka mencapai tujuan pendidikan.

3. Seluk-beluk proses belajar.

4. Hubungan antara metode mengajar dan media pendidikan.

5. Nilai atau manfaat media pendidikan dalam pengajaran.

6. Pemilihan dan penggunaan media pendidikan.

7. Berbagai jenis alat dan teknik media pendidikan.

8. Media pendidikan dalam setiap mata pelajaran. 
9. Usaha inovasi dalam media pembelajaran.

Masalah pendidikan dan pengajaran merupakan masalah yang cukup kompleks dimana banyak faktor yang ikut mempengaruhinya. Salah satu faktor tersebut diantaranya adalah guru. Guru merupakan komponen pengajaran yang memegang peranan penting dan utama, karena keberhasilan proses belajar-mengajar sangat ditentukan oleh faktor guru. Tugas guru adalah menyampaikan materi pelajaran kepada siswa melalui interaksi komunikasi dalam proses belajar-mengajar yang dilakukannya. Keberhasilan guru dalam menyampaikan materi sangat tergantung pada kelancaran interaksi komunikasi membawa akibat terhadap pesan yang diberikan guru.

Penemuan-penemuan baru dalam ilmu dan teknologi telah membawa pengaruh yang sangat besar dalam bidang pendidikan. Perubahan tersebut bukan saja terjadi pada kurikulum, metodologi pengajaran, tetapi juga terjadi dalam bidang administrasi, organisasi, dan personil. Perubahan tersebut merupakan suatu inovasi dalam sistem pendidikan yang mencakup seluruh komponen yang ada. Untuk itu diperlukan tenaga pengajar yang handal dan mempunyai kemampuan (capability) yang tinggi dalam melaksanakan proses belajar mengajar. Guru hendaknya dapat menggunakan peralatan yang lebih ekonomis, efesien, dan mampu dimiliki oleh sekolah serta tidak menolak digunakannya peralatan teknologi modern yang relevan dengan tuntutan masyarakat dan perkembangan zaman. Permasalahan pokok dan cukup mendasar adalah sejauh manakah kesiapan guru-guru dalam menguasai pengguanaan media pendidikan dan pengajaran di sekolah untuk pembelajaran siswa secara optimal sesuai dengan tujuan pendidikan dan pengajaran (Usman, 2002).

Proses pembelajaran yang berlangsung di sekolah masih banyak mengalami hambatan. Hal tersebut berdampak pada proses pembelajaran yang tidak efektif dan efisien sehingga hasil pembelajaran pun jauh dari kompetensi dasar yang seharusnya dikuasai oleh peserta didik. Salah satu pemicu masalah tersebut adalah penggunaan metodologi pembelajaran (teknik dan media) yang digunakan guru kurang tepat, dalam hal ini berkaitan dengan pemanfaatan media pembelajaran di sekolah. Masih banyak guru yang belum atau tidak sama bisa sekali mempergunakan media sebagai alat bantu media pembelajaran, padahal dengan media penyampaian proses belajar mengajar lebih efektif dan efesien dan hasil serta tujuan pembelajaran dapat dicapais dengan baik. Masalah yang sering ditemui di lapangan atau di sekolah-sekolah, mengapa sampai saat ini masih ada guru yang enggan menggunakan media dalam mengajar. Masalah pemanfaatan media ini terjadi di MTs Negeri 1 Pasuruan yang ada di Kabupaten Pasuruan. Pada umumnya guru dalam menyampaikan materi hanya bertumpu pada media pembelajaran yang selama ini digunakan yaitu buku teks sebagai sumber belajar. Sebagian besar guru tidak pernah menggunakan media pembelajaran lain di dalam proses kegiatan belajar mengajar, hal ini berdampak pada proses pembelajaran yang kurang efektif dan efisien dan hasil tujuan pembelajarannya pun tidak sesuai dengan kompetensi dasar yang ditentukan.

Berdasarkan permasalahan yang terdapat di lapangan, mengenai masalah pemanfaatan media pembelajaran dengan ini akan diadakan penelitian tentang "Pemanfaatan Media Pembelajaran Berbasis Audio Visual Dalam Meningkatkan Hasil Belajar Mata Pelajaran IPS Terpadu Pada Siswa Kelas VII Di MTs Negeri 1 Pasuruan".Beberapa penelitian yang pernah dilakukan terkait dengan penggunaan audio visual dalam pembelajaran yaitu Heris Hulay Fitern, dengan judul "Pemanfaaan 9Audio-Visual Video Untuk Meningkatkan Motivasi Dan Prestasi Belajar Sejarah Siswa Kelas X MAN 3 Kediri”. Hasil penelitian menunjukkan bahwa proses 
perencanaan penelitian ini terdapat tiga kali siklus dengan 7 kali pertemuan selama 2 bulan, dalam proses ini pelaksanaanya berjalan dengan baik. Terlihat peningkatan motivasi belajar siswa pada siklus I sebesar 37,9\%, siklus II 70,6\%, siklus III $63,7 \%$, sedangkan untuk prestasi belajar siswa meningkat pada siklus I sebesar 16,1\%, siklus II 22,5\%, siklus III 12,9\%. Selain itu, ada Wisnu Nanda Saputra, dengan judul "Pengembangan Media Pembelajaran Video Ilustrasi Pada Mata Pelajaran Sosiologi Materi Interaksi Sosial".Hasil penelitian menunjukkan bahwa media pembelajaran Video Ilustrasi terbukti secara signifikan dapat meningkatkan hasil belajar siswa kelas $\mathrm{X}$ IPS3 MAN Bangil Pasuruan. Dengan melihat rerata diketahui $\mathrm{X}_{2}$ lebih dari $\mathrm{X}_{1}$ $(88,5>73)$ juga menunjukkan bahwa post tes lebih tinggi dari pada pre test.

\section{METODE}

Pendekatan yang digunakan dalam penelitian ini adalah pendekatan kualitatif. Bogdan dan Taylor mendefinisikan sebagai prosedur penelitian yang menghasilkan data deskriptif berupa kata-kata.( Moleong, 1994:3) Penelitian demikian manusia sebagai instrumen penelitian karena lebih mampu menyesuaikan pada situasi tak tertentu, dapat membangun dari suasana yang tak terkatakan, juga sesuai dengan menerapkan metode, yaitu interview dan observasi.(Noeng, 1995:162)

Nasution dalam penelitian ini diusahakan mengumpulkan data diskriptif yang banyak dituangkan dalam bentuk laporan dan uraian. Penelitian ini tidak mengutamakan angka-angka dan statistik meskipun tidak menolak data kuantitaif.(Prastowo, 2001:43)

Alasan peneliti menggunakan pendekatan ini karena data yang bersifat holistik, kompleks, dinamis dan penuh makna. Sehingga, kurang tepat data pada situasi sosial tersebut diperoleh dengan pendekatan kuantitatif. Penelitian ini dilakukan di MTs Negeri 1 Pasuruan. Penelitian ini akan mendeskripsikan dan menganalisis data berkaitan dengan pemanfaatan media pembelajaran mata pelajaran IPS dalam rangka meningkatan pembelajaran yang efektif dan efisien. Dalam konteks ini fokus penelitian mendeskripsikan dan menganalisis tentang masalah yang dihadapi guru dalam pemanfaatan media pembelajaran di sekolah guna meningkatkan pembelajaran yang berkualitas.

\section{HASIL dan PEMBAHASAN \\ Hasil}

Pelaksanaan Pemanfaatan Media Belajar Pendidikan Ilmu Pengetahuan Sosial dalam Meningkatkan Hasil Belajar Siswa di MTs Negeri 1 Pasuruan.

Pelaksaan pemanfaatan pembelajaran IPS di MTs Negeri 1 Pasuruan berdasarkan hasil wawancara dengan wakil kepala madrasah sarana prasana di MTs Negeri 1 Pasuruan, Bapak Amin Tolibin. S.Pd.I., M.Pd.I., sebagai berikut "Pemanfaatan media pembelajaran di jadwalkan tiap minggu untuk siapa saja yang akan menggunakannya, apabila ada guru yang ingin menggunakan media pembelajaran tetapi tidak dalam jadwalnya maka harus meminta izin terlebih dahulu kepada guru yang jadwalnya memakainya. Karena disini masih jarang guru memanfaatkan media pembelajaran hanya beberapa sajayang menggunakannya dalam pembalajaran". Sedangkan berdasarkan hasil wawancara dengan bu Iflakhah yang menyatakan bahwa: "Proses pembelajarannya sesuai dengan ketentuan RPP yang sudah dibuat yaitu dengan model saintifik". Dari model saintifik ini dapat meningkatkan kreatifitas guru dalam mengembangkan materi. Serta, guru tidak menggunakan metode ceramah saja, namun dengan memanfaatkan fasilitas yang ada 
dengan baik. Jika, guru dapat menggunakan kreatifitas dalam menggunakan metode audio visual. Maka, guru tidak lagi capek berbicara dalam menyampaikan materi. Pelaksaan pemanfaatan pembelajaran IPS di MTs Negeri 1 Pasuruan berdasarkan hasil wawancara dengan salah satu siswa yang menyatakan bahwa: "Dengan menggunakan metode ceramah saja saya kurang bisa memahami apa yang dijelaskan oleh guru hanya bisa di khayal-khayal saja, tanpa mengetahui apa yang dimaksud. Jika menggunakan media audio visual para murid bisa Dengan jelas dan bisa memahami apa yang diterangkan."

\section{Hasil belajar siswa setelah guru menggunakan media audio visual pada mata pelajaran IPS terpadu di MTs Negeri 1 Pasuruan.}

Hasil pembelajaran dengan menerapkan media pembelajaran pada mata pelajaran IPS terpadu untuk meningkatkan hasil belajar siswa kelas VII-A MTs Negeri 1 Pasuruan selain dilihat dari hasil observasi aktifitas siswa juga dengan melalui teknik wawancara. Peneliti memperoleh kecapaian tujuan secara individual melalui pre test dan post test, sebgaimana direncanakan pada tahap perencanaan. Skor rest sebagaimana disajikan tabel berikut :

Tabel 1. Post test

\begin{tabular}{ccc}
\hline Internal Skor & $\mathrm{F}$ & $\mathrm{P}$ \\
\hline 10 & 5 & $8,82 \% \%$ \\
9 & 12 & $29,41 \%$ \\
8 & 12 & $32,35 \%$ \\
7 & 5 & $29,41 \%$ \\
6 & - & - \\
5 & - & -
\end{tabular}

Dari tabel tersebut dapat dinyatakan bahwa hasil belajar siswa berdasarkan KKM pada post test setelah diterapkannya pemanfaatan media belajar pada proses pembelajaran adalah bahwa terdapat 5 siswa yang belum bisa mencapai KKM atau sebesar 7,5 dan terdapat 29 siswa yang TUNTAS dan mampu mencapai KKM atau sebesar. Maka dapat disimpulkan bahwa terdapat peningkatan hasil belajar dari jumlah siswa yang telah mampu mencapai KKM pada post test. Berdasarkan perhitungan tersebut maka dapat diketahui bahwa pada post test terdapat peningkatan hasil belajar siswa melalui pre test ke post test yang diberikan. Peningkatan hasil belajar mencapai 70,58\%. Untuk mendapatkan gambaran kualitatif secara mendalam terhadap penerapan pemanfaatan media pembelajaran pada mata pelajaran IPS terpadu kelas VII-A MTs Negeri 1 Pasuruan, peneliti melakukan wawancara kepada beberapa siswa yang ditetapkan sebagai informan. Menurut siti Fatimah selaku salah satu siswa menjeleskan dengan menggunakan media pembelajaran saya bisa lebih jelas dengan memahami apa yang telah ibu ajarkan tentang materi pembelajaran.

Faktor Penghambat dan Faktor Pendukung Pemanfaatan Media Belajar Pendidikan Ilmu Pengetahuan Sosial.

\section{Faktor pendukung}

a. Adanya fasilitas sarana prasarana yang memadai. Fasilitas sarana dan prasarana sesuai dengan hasil wawancara peneliti yang dilakukan oleh bapak kepala madrasah Najib Kusnanto, S.Ag., M.Si. yang menyatakan bahwa: “Guru itu memiliki godwall 
yang tinggi terhadap KBM nya yaitu guru-guru itu setidak-tidaknya memakai media yaitu IT semua guru IPA dan IPS Terpadu menggunakannya. Rencananya mau membuat ruangan IT khusus untuk melaksanakan kegiatan pembelajaran yang berbasis IT."

b. Motivasi dan etos kerja para pendidik dalam menggunakan media pembelajaran berbasis audio visual. Motivasi dan etos kerja sesuai dengan hasil wawancara peneliti dengan ibu Iflakhah yang menyatakan bahwa: "Dengan adanya motivasi dan etos kerja dari para pendidik bisa membuat kegiatan belajar mengajar lebih menarik lagi dan membuat semangat siswa untuk belajar lebih giat."

c. Kedisiplinan siswa dalam mengikuti kegiatan belajar mengajar di kelas. Masalah kedisplinan siswa dalam mengikuti KBM hasil wawancara peneliti dengan salah satu guru yang menyatakan bahwa: "Siswa dapat mengikuti kegiatan belajar mengajar dengan baik hal ini ditandai tidak adanya siswa yang bolos pada kegiatan belajar mengajar berlangsung."

\section{Faktor penghambat pemanfaatan}

Hasil wawancara peneliti dengan salah satu guru yang menyatakan tentang faktor penghambat bahwa: "Ada beberapa guru yang masih belum memanfaatkan fasilitas yang ada, karena faktor umur maupun jumlah yang belum mencukupi kebutuhan guru dalam mengembangkan kreatifitas". Sedangkan menurut wakil kepala madrasah bidang sarana dan prasarana yang menyatakan bahwa: "Jika, dalam waktu bersamaan ada guru yang menggunakan LCD secara bersamaan. Sedangkan jumlah LCD terbatas, maka salah satu dari guru tersebut harus mengalah”.

\section{Pembahasan}

\section{Pelaksanaan Pemanfaatan Media Belajar Pendidikan Ilmu Pengetahuan Sosial dalam Meningkatkan Hasil Belajar Siswa di MTs Negeri 1 Pasuruan.}

Efektifitas secara umum menunjukkan sampai seberapa jauh tercapainya suatu tujuan yang terlebih dahulu ditentukan, kemudian pembelajaran dikatakan efektif jika terlaksananya semua tugas pokok, tercapainya tujuan, ketepatan waktu, adanya partispasi aktif dari anggota. (Mulyasa, 2002) dan Efektifitas media belajar Pendidikan Ilmu Pengetahuan Sosial yang ada di madrasah dimanfaatkan dengan baik. Hal tersebut dapat dilihat dari terjadi peningkatan hasil belajar pada siswa saat dilaksanakan ulangan harian. Hasil belajar siswa pada ulangan harian pertama dan kedua mengalami peningkatan. Guru menggunakan metode ceramah saja untuk menerangkan materi yang diajarkan kepada para siswa, sehingga siswa kurang faham dengan apa yang diterangkan oleh guru dan siswa merasa bosen atau jenuh karena guru hanya menggunakan metode ceramah saja.

Beberapa penelitian menunjukkan bahwa siswa yang belajar melalui program televisi untuk berbagai mata pelajaran tersebut sama seperti mereka yang mempelajarinya melalui tatap muka dengan guru kelas (Rohani, 1997), dan Pembelajaran tidak hanya dengan menggunakan metode ceramah saja sebagai metode belajar tetapi juga sumber, alat, dan lingkungan. Memanfaatkan alat yang mendukung proses pembelajaran dimadrasah salah satunya LCD. Media yang digunakan didalam kelas membuat siswa lebih bisa mengekspresikan pikiran mereka secara luas dan terarah. Adanya media membuat mereka mempunyai gambaran tentang apa yang dilihatnya secara langsung yaitu berupa foto maupun video terkait materi. Hal ini merupakan salah satu manfaat dari media belajar, yakni menyajikan sesuatu yang tidak mungkin dikunjungi, diadakan, atau dilihat secara langsung dan konkret. 
Siswa mengikuti pembelajaran dengan berbagai media belajar dan sarana parasana yang mendukung di madrasah. Materi dapat tersampaikan dan dipahami dengan baik oleh siswa ketika mereka mendengarkan apa yang diterangkan oleh guru. Siswa banyak yang tidak memperhatikan pelajaran karena mereka merasa bosan dengan hanya menggunakan satu media saja. Dengan memanfaatkan berbagai media yang tersedia membuat para siswa lebih memperhatikan pelajaran dan dapat meningkatkan hasil belajar mereka.

Guru memanfaatkan segala media belajar yang ada dimadrasah secara bergantian. Pengguanaan LCD merupakan salah satu media belajar yang ada di madrasah. Ketika guru ingin menerangkan sesuatu materi yang tidak bisa di gambarkan dengan baik dengan menggunakan metode ceramah, guru bisa menggunakan media belajar dengan menerengkan apa yang ada di foto atau di video tersebut. Pembelajaran yang dilaksanakan dengan menggunakan media belajar membuat siswa tidak jenuh, karena mereka bisa dengan jelas melihat apa yang diterangkan oleh guru tersebut.

Hal tersebut sesuai dengan prinsip pemilihan media pembelajaran yaitu Pemilihan media harus sesuai dengan gaya belajar siswa serta gaya dan kemampuan gutru. Oleh sebab itu, perlu memahami karakteristik serta prosedur penggunaan media yang dipilih. Pemilihan media harus sesuai dengan lingkungan, fasilitas dan waktu tersedia untuk kebutuhan pembelajaran.( Sanjaya, 2008)

Pemanfaatan media belajar Pendidikan Ilmu Pengetahuan Sosial dapat berjalan dengan baik dan lancar, karena setiap siswa mengikuti pembelajaran dengan bersemangat dan antusias. Pelaksanaan pemanfaatan media belajar Pendidikan Ilmu Pengetahuan Sosial ini guru mengatur penggunaan media belajar secara bergantian. Sebelum menggunakan media belajar guru telah mempersiapkan terlebih dahulu media belajar apa yang akan digunakan dalam pembalajaran.

Berbagai media belajar dan sarana prasarana yang dimanfaatkan secara bergantian dapat membuat siswa tidak jenuh ketika pembelajaran berlangsung. Dengan memanfaatkan segala media belajar yang ada membuat siswa lebih memahami materi yang disampaikan oleh guru. Pemahaman siswa akan materi yang diajarkan guru dapat dilihat pada nilai ulangan, yang merupakan hasil belajar siswa. Peningkatan hasil belajar siswa terjadi ketika mereka mampu menguasai materi apa yang disampaikan oleh guru.

\section{Hasil belajar siswa setelah guru menggunakan media audio visual pada mata pelajaran IPS terpadu di MTs Negeri 1 Pasuruan.}

Menurut Ahmad Rohani dalam bukunya member pengertian bahwa "media audio visual adalah media instruksional modern yang sesuai dengan perkembangan zaman (kemajuan ilmu pengetahuan dan teknologi), meliputi media yang dapat dilihat, didengar dan yang dapat dilihat dan didengar" (Rohani, 1997).

Dari data yang diperoleh, setelah guru menggunakan media audio visual pada mata pelajaran IPS terpadu maka guru mengadakan evaluasi hasil belajar yang merupakan proses untuk menilai belajar siswa melalui kegiatan penilaian dan pengukuran hasil belajar. Tujuannya untuk mengetahui kemajuan siswa dalam suatu kurun waktu proses belajar tertentu. Hal ini berarti dengan evaluasi guru dapat mengetahui kemajuan perubahan tingkah laku siswa sebagai hasil proses belajar dan mengajar yang melibatkan dirinya selaku pembimbing dan pembantu kegiatan belajar siswa.

Untuk menghasilkan nilai yang baik guru melakukan evaluasi formatif dan evaluasi sumatif. Yang dimaksud dengan evaluasi formatif adalah aktivitas guru dan siswa yang 
dimaksudkan untuk memantau kemajuan belajar siswa selama proses belajar berlangsung. Penilaian ini akan memberikan umpan balik bagi penyempurnaan program pembelajaran, mengetahui dan mengurangi kesalahan yang memerlukan perbaikan (Sadler, 1989). Dengan demikian, penilaian formatif berprentasi kepada proses belajar mengajar. Dengan penilaian formatif diharapkan guru dapat memperbaiki program pengajaran dan strategi pelaksanaanya, sedangkan evaluasi sumatif adalah suatu aktivitas penilaian yang menghasilkan nilai atau angka yang kemudian digunakan sebagai keputusan pada kinerja siswa (Irons, 2008). Tujuannya adalah untuk melihat hasil yang dicapai oleh siswa, yakni seberapa jauh tujuan-tujuan kurikuler dikuasai oleh siswa.

Jadi, hasil belajar siswa setelah guru memanfaatkan media audio visual pada mata pelajaran IPS terpadu sangat baik sekali. Rata-rata siswa banyak mendapatkan hasil yang baik. Dengan begitu pemanfaatan media audio visual pada mata pelajaran IPS terpadu sangat bermanfaat sekali bagi guru dan siswa, karena guru lebih mudah menjelaskan materi-materi tentang IPS terpadu dan menjadikan siswa yang pintar, cermat dan berintelektual.

\section{Faktor Penghambat dan Faktor Pendukung Pemanfaatan Media Belajar Pendidikan Ilmu Pengetahuan Sosial. \\ 1. Faktor pendukung}

a. Adanya fasilitas sarana prasarana yang memadai. Adanya fasilitas sarana prasarana yang memadai membuat siswa lebih mudah menerima materi yang disampaikan oleh guru. Bukan hanya itu saja, guru juga diuntungkan dengan fasilitas sarana dan prasarana yang memadai guru bisa dengan leluasa mengembangkan kreatifitasnya dalam mengembangkan materi yang akan disampaikan.Yang dimaksud adanya fasilitas sarana dan prasarana yang memadai ditandai dengan missal adanya LCD disetiap kelas.

b. Motivasi dan etos kerja para pendidik dalam menggunakan media pembelajaran berbasis audio visual. Motivasi dan etos kerja para pendidik bisa meningkatkan kreatifitas dalam mengembangkan materi. Missal, dalam menggunakan media pembelajaran berbasis audio visual guru dapat menggunakan aplikasi tertentu untuk menyampaikan materi yang akan disampaikan.

c. Kedisiplinan siswa dalam mengikuti kegiatan belajar mengajar di kelas.. Adanya kedisiplinan siswa dalam mengikuti kegiatan belajar mengajar di kelas membuat guru tidak mengulang kembali materi yang disampaikan.

\section{Faktor penghambat pemanfaatan}

Faktor penghambat utama yaitu kurangnya kesadaran pendidik dalam pemanfaatan media pembelajaran berbasis audio visual di madrasah. Kurangnya kesadaran pendidik dalam pemanfaatan media pembelajaran berbasis audio visual di madrasah ditandai adanya guru yang dapat memanfaatkan fasilitas yang ada. Selain itu faktor umur yang mempengaruhi dalam mengembangkan kreatifitas guru.

\section{KESIMPULAN}

Dari hasil penelitian mengenai pemanfaatan media pembelajaran berbasis audio visual Pendidikan Ilmu Pengetahuan Sosial dalam meningkatkan hasil belajar siswa yang telah dibahas dalam bab sebelumnya, maka dapat disimpulkan : 
1. Pembelajaran tidak hanya dengan menggunakan metode ceramah saja sebagai metode belajar tetapi juga sumber, alat, dan lingkungan. Memanfaatkan alat yang mendukung proses pembelajaran dimadrasah salah satunya LCD. Pelaksanaan pemanfaatan media belajar Pendidikan Ilmu Pengetahuan Sosial ini guru mengatur penggunaan media belajar secara bergantian. Sebelum menggunakan media belajar guru telah mempersiapkan terlebih dahulu media belajar apa yang akan digunakan dalam pembalajaran.

2. Guru mengadakan evaluasi hasil belajar yang merupakan proses untuk menilai belajar siswa melalui kegiatan penilaian dan pengukuran hasil belajar. Untuk menghasilkan nilai yang baik guru melakukan evaluasi formatif dan evaluasi sumatif.

3. Kegiatan pemanafaatan media belajar Pendidikan Ilmu Pengetahuan Sosial tentu saja mengalami hambatan atau kendala dan dukungan dalam pelaksanannya. Hambatan adalah faktor-faktor yang menghambat dalam pemanfaatan media belajar Pendidikan Ilmu Pengetahuan Sosial. Dalam pemanfaatan media belajar Pendidikan Ilmu Pengetahuan Sosial untuk meningkatkan hasil belajar siswa MTs Negeri 1 Pasuruan ditemukan beberapa faktor yang menghambat antara lain kurangnya alat yang tersedia di sekolah. Selain faktor penghambat, dalam pemanfaatan media belajar Pendidikan Ilmu Pengetahuan Sosial untuk meningkatkan hasil belajar siswa MTs Negeri 1 Pasuruan ditemukan beberapa faktor yang mendukung antara lain adanya kerjasama dengan keluarga, media yang mendukung proses pembelajaran.

\section{DAFTAR PUSTAKA}

Ahmad Rohani. 1997. Media Instruksional Education. Jakarta: Rineka Cipta.

Andi Prastowo. 2001. Metode Penelitian Kualitatif Dalam Presfektif Rancangan Penelitian. Jogjakarta: Ar-Ruzz Media.

Arsyad, Azhar. 2002. Media Pembelajaran. Jakarta: PT Rajagrafindo Persada

Irons, A. 2008. Enhancing Learning Through Formative Assessment and Feedback. Oxon: Routledge.

Moleong, Lexy J. 1994. Metode Penelitian Kualitatif. Bandung: PT. Remaja Rosdakarya.

Mulyasa, E. Manajemen Berbasis Sekolah, Bandung : PT . Citra Aditya Bakti, 1994

Noeng Muhajir. 1995. Metodologi Penelitian Kualitatif. Yogyakarta: Rakesarasin, Edisi Revisi III.

Sadler, R., D. 1989. Formative Assessment and The Design of Instructional Systems. Instructional Science. 18,

Sanjaya, wina. 2008. Perencanaan \& Desain Sistem Pembelajaran. Jakarta: KENCANA.

Sudjana, Nana. 2002. Media Pengajaran. Bandung: Sinar Guru Algesindo

Usman, M.Basyiruddin dan Asnawir. 2002. Media Pembelajaran Jakarta: Ciputat Pers. 